\title{
Scorpion maintenance in captivity for venom extraction in Costa Rica
}

\author{
Emanuel Brenes ${ }^{1 *}$ \& Aarón Gómez ${ }^{2}$ \\ 1. Escuela de Ciencias Biológicas, Universidad Nacional, 3000 Heredia, Costa Rica; ebrenex@gmail.com \\ 2. Instituto Clodomiro Picado, Facultad de Microbiología, Universidad de Costa Rica, 2060 San José, Costa Rica; \\ aaron.gomez@ucr.ac.cr
}

Received 09-IX-2015. C Corrected 03-III-2016. $\quad$ Accepted 04-IV-2016.

\begin{abstract}
Approximately 2000 scorpion species can be found around the world; although few species are considered "harmful" to human beings, a high number of scorpionism cases are reported all over the world. The elaboration of anti-scorpion sera requires the establishment of an animal collection maintained in captivity for venom extraction purposes. The Clodomiro Picado Institute (ICP, for its acronym in Spanish), poses a vast trajectory in manufacturing snakebite antivenoms, and starts a scorpion collection in 2005 for this purpose. In total, 2043 scorpions were classified in 11 species and collected during a seven-year period using a black-light flashlight and an intensive seeking methodology. The scorpions were collected from several localities of the Pacific and the Caribbean versants of Costa Rica. The venom extraction was performed by applying electrostimulation; the collected venom was characterized by total protein content in addition to median lethal doses. Centruroides bicolor showed higher amounts of venom yield, total protein content and more lethal dose, all of which were correlated with its body mass. The techniques used to keep scorpions in captivity allowed the animals to live several years. Longevity analysis showed significant differences among scorpion genera $(\mathrm{H}=353.80 ; \mathrm{df}=3 ; \mathrm{P}<0.0001)$; moreover, the genus Didymocentrus lived longer with an average of 4.46 years. One key factor of its longevity was that it did not go through venom extraction processes. Additionally, a high survival rate of Tityus pachyurus born in captivity, compared to other species within the same genus, was observed $(\mathrm{H}=94.32 ; \mathrm{df}=3 ; \mathrm{P}<0.0001)$. This characteristic should be taken into consideration, when programs of reproduction in captivity are designed. In conclusion, the maintenance of a scorpion collection was efficient for venom extraction purposes and a longer life expectancy of the animals. Moreover, there is a scarcity on publications regarding scorpion maintenance in captivity for venom extraction purposes; therefore, a deeper research in aspects such as reproduction, death causes and feeding behaviors is required. Rev. Biol. Trop. 64 (3): 1019-1027. Epub 2016 September 01.
\end{abstract}

Key words: Costa Rican scorpions, maintaining scorpions, captive scorpions, scorpion venom, venom extraction.

Approximately 2000 species of scorpions can be found around the world, and are classified in 15 families (Fet \& Soleglad, 2005; Rein, 2013). Very few of these animals are considered "dangerous" for human beings, and the main scorpionism cases have been reported for regions such as: Australia (Isbister, Volschenk, \& Seymour, 2004), Asia (Dehghani, Vazirianzadeh, Nasrabadi, \& Moravvej, 2010), Africa (Laïd et al., 2012), and America: especially Latin America (Borges, Miranda, \& Pascale, 2012). An approximate number of 30 species of scorpions are potentially harmful for human beings, where 19 species belong to the family Buthidae, and the genus Centruroides and Tityus, found in America (Chippaux \& Goyffon, 2008). The Centruroides genus is distributed from the North part of the American continent to Central America, and the Tityus genus is found from Central America through South America (Borges et al., 2012).

The highest annual incidence of scorpion stings in America occurs in Mexico, with 2050 scorpion stings by 100000 inhabitants (Chippaux \& Goyffon, 2008). Other Latin American countries have lower scorpion sting incidence, 
for instance Brazil, Venezuela and Colombia with values of $142,40,5$ scorpion sting by 100000 inhabitants, respectively. It is worth mentioning that some of these scorpion stings end up in fatalities, especially in children (Chippaux \& Goyffon, 2008). Due to the scorpionism occurrence in Latin America, the need for an antivenom elaboration has emerged. Thus, several commercial antivenoms are produced in different countries such as Brazil (Candido \& Lucas, 2004), Mexico (Chippaux \& Goyffon, 2008) and Venezuela (Poggioli De Scannone, 1996).

In Central America the studies on scorpions are scarce, probably due to the reduced amount of species that inhabit these countries. Costa Rica reports 14 species within seven genera and four families; with the genus Centruroides and Tityus presenting medical importance due to their envenomation features. Moreover, these two genera represent an emerging potential problem to the public health system, for Costa Rica and the other Central American countries (Leveridge, 2000).

In Costa Rica, the Clodomiro Picado Institute has a remarkable work on research and elaboration of snakebite antivenoms (Rojas, Jiménez, \& Gutiérrez, 1993); however, the scorpionism was not been attended until now. Furthermore, the National Center of Intoxication has reported an increased number of scorpion stings in the country since the 90 's decade: only 24 cases for 1992, 206 cases in 1998 , and 405 cases in 1999, practically a $100 \%$ increase (Leveridge, 2000). The current problem is that there is no proper antivenom for its treatment, and the gap between the scorpionism stings problem and an effective treatment became evident. Considering the scorpion stings relevance in public health and the potential harm that it may cause, the Clodomiro Picado Institute decided to study the toxins of the major scorpion species inducing pathologic effects, as well as the establishment of a live animal maintenance installation for venom extraction purposes.

Nowadays, the establishment of collections in captivity of animals that may cause a public health impact is fundamental. The elaboration of scorpion antivenoms requires the establishment of a collection in order to maintain the animals and for venom extraction. A previous effort was made by Bucherl of the Butantán Institute, that described the techniques for keeping a live collection of scorpions in laboratory conditions for venom extraction purposes (Whittemore, Keegan, Fitzgerald, Bryant, \& Flanigan, 1963). Thus, the aim of this work was to report the experiences gathered in keeping a live collection of Costa Rican scorpions, for venom extraction, at the Clodomiro Picado Institute.

\section{GENERAL PROCEDURES AND PRELIMINARY FINDINGS}

An emergence and importance of the scorpionism in Latin America has increased in the last few years, especially in countries such as Costa Rica, where hundreds of scorpion stings have been reported, including one fatality in 1995 (Leveridge, 2000). For this reason, a group of scientists of the Clodomiro Picado Institute, started a research project on the characterization and, eventually, of a pilot antiscorpion serum batch elaboration.

Scorpions capture field trips: Scheduled field trips were conducted from 2005 through 2011 to the following locations: Santa Rosa National Park, Palo Verde National Park, Quepos, Playa Piro, Cabo Blanco and Carara in the Pacific versant; Hitoy Cerere National Park, Chiroles, La Selva Biological Station, Siquirres, Guayacan, Barbilla National Park and La Gamba in the Caribbean versant of Costa Rica (Fig. 1). Additionally, some scorpions were provided by particulars. The scorpions were collected using an ultraviolet flashlight and an intensive seeking strategy; captured scorpions were transported to the Clodomiro Picado Institute located in Dulce Nombre de Coronado, San José, Costa Rica; and were registered in the collection. The following species were collected during such field trips: Ananteris platnicky (Lourenço, 1982), Didymocentrus 


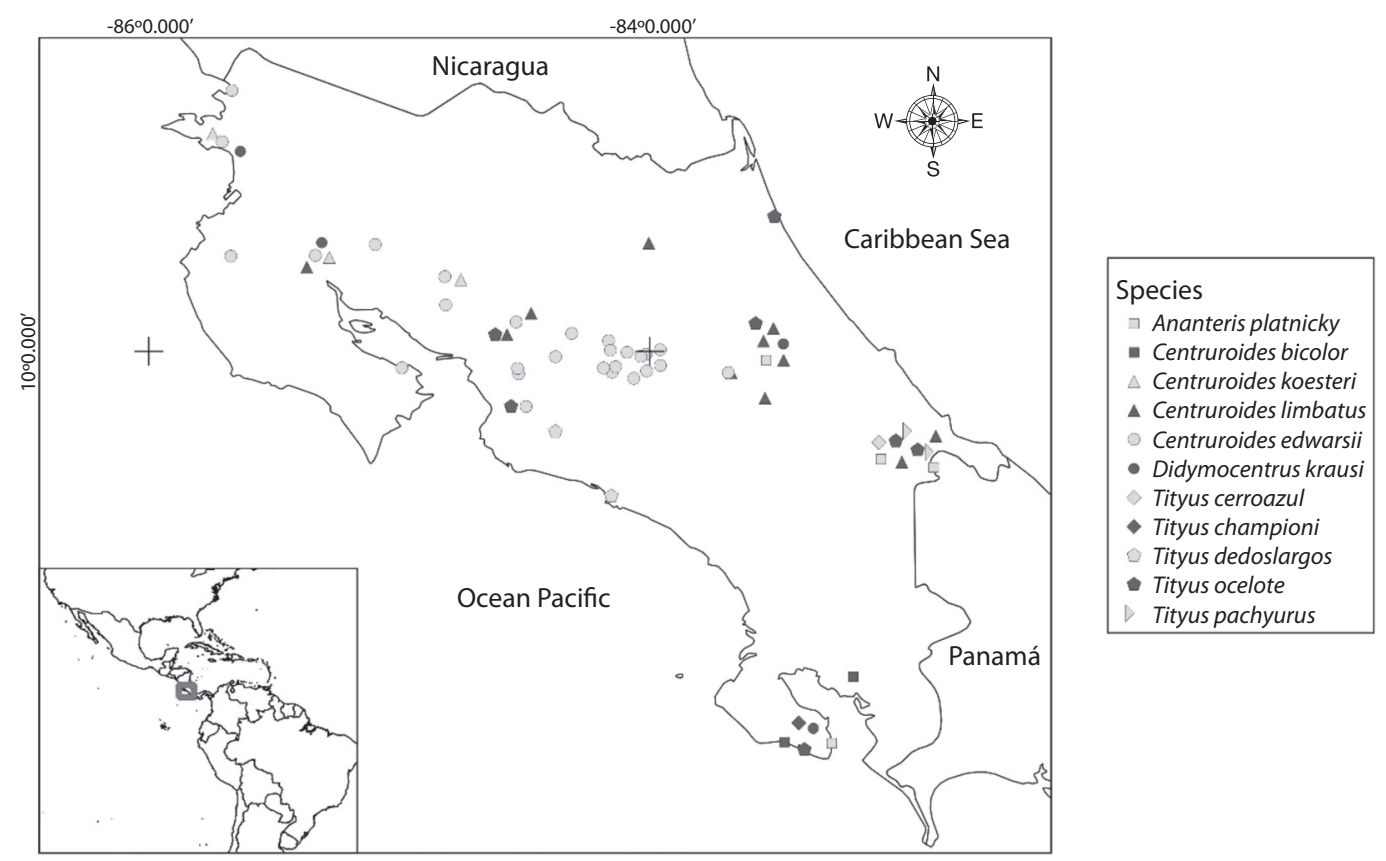

Fig. 1. Scorpion collecting sites in Costa Rica during field trips conducted by the Clodomiro Picado Institute.

krausi (Francke, 1978), Centruroides edwardsii (Gervais, 1843), C. koesteri (Kraepelin, 1911), C. bicolor, C. limbatus, Tityus championi and T. pachyurus (Pocock, 1898), T. cerroazul (Lourenço, 1986), T. dedoslargos and T. ocelote (Francke \& Stockwell, 1987).

On the other hand, $88 \%$ of the animals were collected by the Clodomiro Picado Institute staff during field trips. In Santa Rosa, Guanacaste, 800 scorpions were captured during several field trips. The most common species found in this locality was C. edwardsii, however, $C$. koesteri and D. krausi individuals were collected as well. Other collecting sites included Palo Verde National Park, located in Guanacaste; where the same species of scorpions were found. Additionally, Playa Piro, Península de Osa, Puntarenas was visited, where the totality of $C$. bicolor and T. championi scorpions were found (Fig. 1).

The majority of specimens captured belong to the genus Centruroides, being C. edwardsii the most well-known scorpion in the country, especially by people in the North Pacific and Central Valley of Costa Rica. The species of this genus in Costa Rica can tolerate alterations in the forest and are even well adapted to urban environments (Víquez, 1999). On the other hand, C. limbatus is the most common species in the Caribbean, and C. bicolor the most common in the South Pacific (Víquez, 1999). Scorpions of the genus Tityus showed arboreal habits and can be found in unaltered to less altered forests (Borges et al., 2012); this made its observation and capture difficult, resulting in less encounters.

Maintenance in captivity: Considering the first and last register in the animal collection, the maintenance in captivity of these animals had a duration of nine years (2005-2013), resulting in 2043 scorpions in total, classified in 11 species (Fig. 2A). The arrival of the animals was inconsistent throughout this period, showing highs and lows in the animal registration. Furthermore, since 2009, the scorpion's arrival showed a marked decrease with almost none in the last two years (Fig. 2B).

In the Clodomiro Picado Institute, within the Serpentarium section, a $15 \mathrm{~m}^{2}$ laboratory 

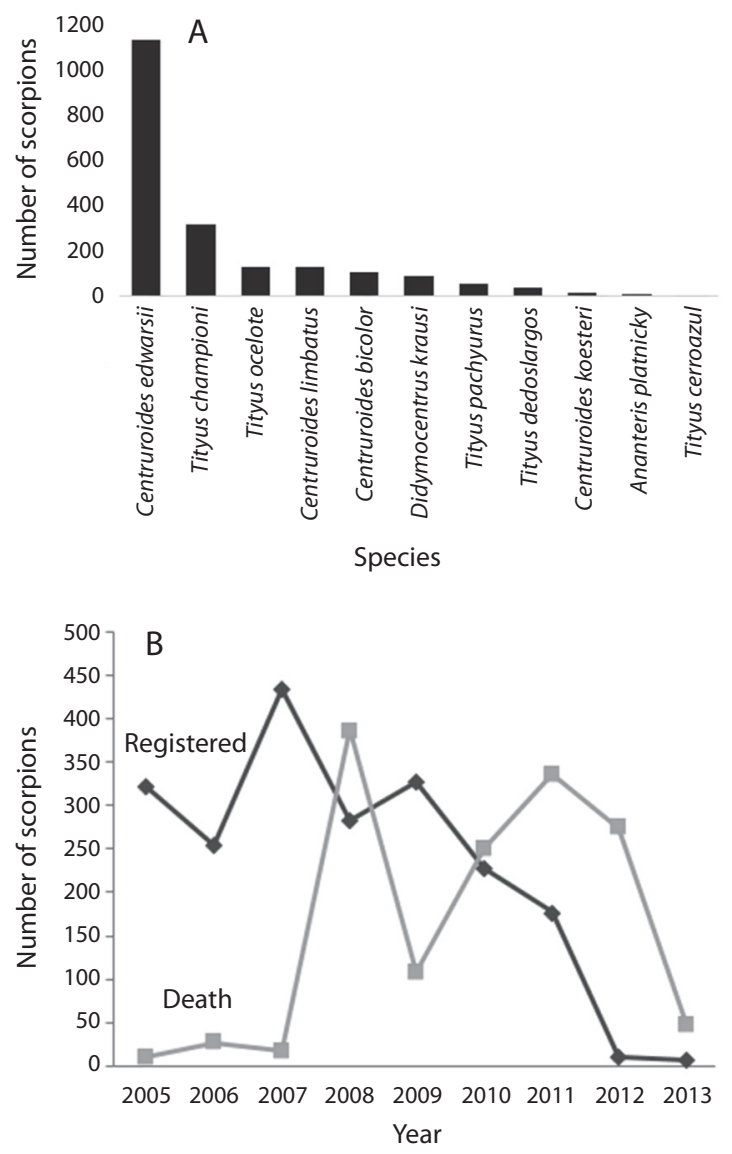

Fig. 2. A. Number of individuals by species in the collection of the Clodomiro Picado Institute. B. Number of scorpions that were registered and deaths by year in the Clodomiro Picado Institute.

was used to house the scorpions. The average temperature and relative humidity recorded during the day was $22.8{ }^{\circ} \mathrm{C}$ and $76 \%$, respectively. The scorpions were maintained individually in plastic cages $(17 \mathrm{~cm}$ diameter and $5.5 \mathrm{~cm}$ height) to avoid cannibalism. Inside the cages, a $\mathrm{Kraft} \AA$ paper piece was included, providing shelter to the scorpions; in addition, a wet cotton ball was included as a water source. Each cage was identified with the general information of the individual, and was organized by species in the laboratory shelves.

On a weekly basis, each cage was subject to a general cleaning process, removing the remains of preys, and cleaning the feces with cotton, or replacing the container when necessary. The Kraft ${ }^{\circledR}$ paper and cotton ball were replaced weekly as well. Food was provided every 15 days with three types of preys: Tenebrio molitor larvae, Acheta domestica crickets and several species of cockroaches. The preys were also raised and maintained at the Institute.

The feeding behavior observed in the genus Centruroides and Didymocentrus was predominantly active, capturing the prey immediately after it was deposited in the cage. The scorpions captured the prey with the pedipalps and inoculated venom rapidly, stinging the prey as many times as necessary to subdue it; they ate it later. On the other hand, the Tityus genus was not prone to subdue the prey immediately; but the preys were eaten in a similar way as the other genera. Additionally, the genus Tityus tended to stand more frequently on the wet cotton balls. 
The feeding behavior needs further investigation, since a methodological design applicable to each species was considered necessary. It is possible that scorpions of the genus Centruroides and Didymocentrus are active predators, while the genus Tityus might be sit-and-wait or ambush predators (Polis, 1990).

The environmental conditions, substratum, feeding programs, feeding items and hydration we used were the same as those employed in the maintenance of collections of scorpions, spiders, insects and other arthropods worldwide. Nevertheless, most of the Costa Rican species tend to fall into cannibalism when kept in captivity, requiring individual maintenance. This feature is contradictory to the reports of the Butantán Institute, where up to 300 scorpions could be maintained in one single box, provided with corrugated cardboard acting as shelter and preventing stress conditions and cannibalism (Candido \& Lucas, 2004).

The maintenance conditions of the live collection were carefully controlled, yet a high number of deaths were registered during the entire captivity period. One of the main problems related to this issue was inanition, either because the scorpion rejected the prey, or because the use of the wrong size of prey to feed the animals. When the scorpion did not eat the prey, a decomposition process began inside the cage, which could trigger the appearance of fungus, which might be another cause of death.

Additionally, the presence of other arthropods such as mites, spiders, collembolans and psocoptherans, whose origin is unknown, could affect the scorpions. One of the mites identified was Tyrophagus putrescentiae, may have contacted the scorpions through the grains used to feed the preys, such as crickets and mealworm beetles.

On the other hand, scorpions showed a high dehydration tolerance, especially those who live in desert conditions. The most important water source in the wild is obtained from preys (Polis, 1990); nonetheless, dehydration could be considered a death cause in scorpions. However, in laboratory conditions, scorpions drink water from other sources, especially when food items are not adequate for them (Polis, 1990).

Additionally, the major death cause in collections to gather venom is precisely the venom extraction processes and the stress it causes. We observed that scorpions that were not subject to venom extraction processes lived longer (i.e. D. krausi, 4.47 years average) than those submitted to repeated venom extraction processes (Oukkache, Chgoury, Lalaoui, Cano, \& Ghalim, 2013).

Newborns and longevity: The animals born in captivity were separated from their mothers when they fell off the mother's back. They were placed together in a terrarium that was provided with water, and were fed with the first larval stages of Tenebrio molitor. By the time of the second molt, the newborns were placed in individual cages and were registered in the collection.

The implementation of a digital database allowed the analysis of general information about the status of the collection through the years. Thus, information such as: amount of animals registered by species, number of species, locations, newborns, number of deaths and longevity was analyzed. Additionally, a distribution map was made, that included the locations from which the animals were collected (using the geographic coordinates of each site and geo-referenced using Qgis v2.8.2 software).

A Non-parametric Kruskal-Wallis test was used to assess the longevity in captivity of the different genus, as well as the differences in longevity of the genus Tityus born in captivity. In addition, a post-hoc test was used to evidence the main differences among the groups. All the tests were performed using $\mathrm{R}$ v3.2.1 software, and values of $\mathrm{P}<0.05$ were considered as statistically significant.

The adaptability to captivity was analyzed by the longevity of each individual of the different species (time since it was first registered in the collection until its death). For these analyses, information concerning 1614 scorpions was employed. Thus, significant differences in the longevity in captivity of the different 
genus was found $\left(\mathrm{H}_{3}=353.8 ; \mathrm{P}<0.001\right)$, with the genus Didymocentrus showing a longer time in captivity with an average of 4.47 years, followed by Centruroides with an average of 2.99 years, and finally Tityus, with only 1.07 years in captivity.

In addition, the different species born in captivity showed significant differences in their longevity $\left(\mathrm{H}_{3}=94.32 ; \mathrm{P}<0.001\right)$; for which, $T$. pachyurus had a higher life expectancy with an average of 1.79 years in captivity when compared to other species.

Most of the scorpions born in captivity die rapidly, which is a common feature within the juvenile scorpions with survival rates reported of just $5 \%$ (Gopalakrishnakone, Cheah, \& Gwee, 1995). This is mainly due to difficulties in facilities, food sources (i.e. prey sizes), and more specialized professionals to take care of the collection (Candido \& Lucas, 2004). On the other hand, in Costa Rica, the genus Tityus shows a dependency towards more humid habitats, since they can be found in very humid forests and are associated to vegetation. Thus, the laboratory conditions could not be suitable for this particular genus; nonetheless, the scorpions T. pachyurus born in captivity tolerated the existing laboratory conditions and lived longer than those captured in the wild. This feature could be important in the establishment of a well-developed animal colony for venom extraction purposes.

Venom extraction and yield: The venom extraction processes were conducted three times per year only on C. edwardsii; whilst for C. bicolor, T. championi and T. pachyurus, the venom extraction process took place once a year. This procedure employed the same individuals in each process, and the new incoming animals were added to the procedures, mainly in the case of venom extractions of C. edwardsii.

The device used as electro-stimulator was composed of an electric converter unit (General Electric $\left({ }^{\circledR}\right)$, where the alternate electric current $(120 \mathrm{~V})$ was converted and regulated to provide the micro-volts needed to perform the electrostimulation, a plate supporting the electrodes and a pedal switch to activate the electrostimulus (both homemade). The venom was obtained by electrostimulation of the venom glands located at the telson. For this, each individual was held by the last segment of the tail, and was placed between two electrodes, producing an electro-stimulus of 0.7-0.8 $\mathrm{mV}$. The released venom was collected in a capillary tube and deposited in an Eppendorf tube $(0.5 \mathrm{~mL})$, that was kept cold $\left(4-8^{\circ} \mathrm{C}\right)$ during the extraction process.

On the other hand, for C. edwardsii three venom extraction processes per year were conducted during the first six years, with a total of 19 extractions (just one venom extraction for last year); resulting in the highest venom yield (Table 1). For the rest of the species, the venom extraction processes were less frequent, and few species were not even extracted due to its availability.

This process of electro-stimulation has proved to be the most effective technique in terms of quantity and quality of the venom extracted (Oukkache et al., 2013). The venom yield of each species is consequent with the body mass of the scorpions. Thus, the highest

TABLE 1

Total venom yield, total protein content and median lethal dose of the main scorpion species maintained at the Clodomiro Picado Institute, Universidad de Costa Rica

\begin{tabular}{lcccccc}
\multicolumn{1}{c}{ Species } & $\begin{array}{c}\text { Number of } \\
\text { extractions }\end{array}$ & $\begin{array}{c}\text { Average of } \\
\text { individuals }\end{array}$ & $\begin{array}{c}\text { Venom yield } \\
(\mathrm{mg})\end{array}$ & $\begin{array}{c}\text { Average venom yield } \\
\text { by individual }(\mathrm{mg})\end{array}$ & $\begin{array}{c}\text { Total Protein } \\
\text { content }(\mathrm{mg} / \mathrm{mL})\end{array}$ & $\begin{array}{c}\mathrm{LD}_{50} \\
(\mu \mathrm{g} / \mathrm{g} \mathrm{mice})\end{array}$ \\
Centruroides edwardsii & 19 & 200 & 1269.3 & 0.40 & 1.11 & 4.4 \\
Tityus championi & 5 & 71 & 137.6 & 0.39 & 1.07 & 3.9 \\
Centruroides bicolor & 5 & 23 & 122.8 & 1.07 & 1.43 & 3.4 \\
Tityus pachyurus & 3 & 15 & 5.1 & 0.11 & 0.93 & 4.1 \\
\hline
\end{tabular}


venom yield $(1.07 \mathrm{mg})$ corresponded to $C$. bicolor, which is a large scorpion (reaching $12 \mathrm{~cm}$ in total length); the lowest venom yield (0.11 mg) was obtained from T. pachyurus, whose average body size is $5 \mathrm{~cm}$. These amounts of venoms were suitable for the development of antivenoms, since a minimum of $0.4 \mathrm{mg}$ are required for the scorpion antivenom elaboration (Candido \& Lucas, 2004).

Venom storage, characterization and evaluation: The venom collected was pooled by species, and kept at $-20{ }^{\circ} \mathrm{C}$ in $2.0 \mathrm{~mL}$ Eppendorf tubes, until it was processed. The venom procedures consisted in centrifuging the venom at $12000 \mathrm{rpm}$ (15 $294 \mathrm{~g}$ ) for five minutes; then, the supernatant was collected and the pellet discarded. The supernatant was frozen at $-90{ }^{\circ} \mathrm{C}$ and lyophilized for 24 hours. The solid venom was weighed and stored at $20{ }^{\circ} \mathrm{C}$ until it was used.

The venom was characterized by total protein content using a Thermo Scientific NanoDrop 2000 C ® Spectrophotometer; using the software NanoDrop 2000 / 2000 C version 1.4.2, Thermo Fisher Scientific (copyright 2009). The total protein content was determined by absorbance at $280 \mathrm{~nm}$ with equivalence of $1 \mathrm{abs}$ unit $=1 \mathrm{mg} / \mathrm{mL}$. We found similar values for all the species studied, with the exception of T. pachyurus, whose total protein content was relatively lower (Table 1). Likewise, the highest total protein content was found in C. bicolor and the lowest protein content in T. pachyurus, which is in correlation with the body mass and the amount of venom yielded.

Additionally, we evaluated the venoms toxicity by the median lethal dose $\left(\mathrm{LD}_{50}\right)$ as described by Solano et al. (2010). Our results showed that $C$. bicolor venom had a higher toxicity, and T. pachyurus and C. edwardsii a lower toxicity (Table 1) than the other species. Toxicity of venoms can be related to the type of preys (Polis, 1990); C. bicolor showed the highest toxicity among the species studied, and this might be in correlation with the size and type of preys it feeds. This particular feature may be useful in preying on larger animals, where a high quantity and more lethal venom is required.

A group of five rabbits were used in the development of a pilot anti-scorpion serum. The immunization scheme was as follow: six inocula every 15 days using Complete Freund's coadjutant, and two boosters every 22 days employing Incomplete Freund's coadjutant. Decreasing amounts of venom $(300,150,75$, $37.5,18.75$, and $9.5 \mathrm{ug}$ ) were used in each inoculum; and a venom solution of $500 \mathrm{uL}$ (w / v) in a final solution (venom-adjuvant); the final volume of inoculation was $2 \mathrm{~mL}$ via subcutaneous and multiple sites of injections. Nevertheless, the anti-scorpion serum resulted unable to neutralize the lethal dose used to challenge the venom toxicity. The elaboration of a pilot anti-scorpion serum showed several difficulties in order to raise an acceptable titer of antibodies capable to neutralize the venom toxicity. Previous studies have also found that the anti-scorpion sera have a relative low effective action (Borges et al., 2012). Several factors may have influenced this result: small doses of venoms, frequency of inoculation, use of adjuvants and immunogenicity of the proteins in venom, among others. Additional, research should contribute to find effective protection against scorpion venom toxicity.

\section{GENERAL CONCLUSIONS}

The scorpion collection kept along the nine-year period showed to be efficient in terms of venom extraction processes, venom yield and relatively good survival of animals. However, several weaknesses were found, leaving aside important information on nutrition, behavior, growth and development, and environmental conditions. In spite that there is vast information concerning scorpionism, its toxins and the effect of the stings in public health (Lourenço et al., 1996; Batista et al., 2007; Chippaux \& Goyffon, 2008), there is scarce information regarding the collection and establishment of scorpion colonies for venom extraction purposes. Although, there are several countries (i.e. Brazil, Mexico, Venezuela) currently working 
in the development of a scorpion antivenom, we concluded that a deeper investigation on the factors causing deaths in scorpion collections in captivity is necessary. Besides, the improvement of maintenance conditions in laboratories and the breeding procedures of scorpions are imperative, in order to produce the venom required for antivenom elaboration.

\section{ACKNOWLEDGMENTS}

This work was partially funded by the Vicerrectoría de Investigación, University of Costa Rica with the projects: 741-A5048 and 741-B2-081. The Clodomiro Picado Institute partially funded the maintenance of the live collection of scorpions. For the contribution in collecting and maintaining the collection, the authors thank: Jazmín Arias, Fabián Bonilla, Danilo Chacón and Santos Rodríguez, staff members of the Clodomiro Picado Institute. Special thanks to interns and volunteers: Carolina Vega, Carmen Vásquez, Jennifer Rivera, Olga Durán, Rebeca Hidalgo and Mauricio De la O. Also, the authors thank Pamela Zúñiga for reviewing the English grammar of the manuscript.

\section{RESUMEN}

Experiencias del mantenimiento en cautiverio de escorpiones en Costa Rica para la extracción de veneno. Existen alrededor de 2000 especies de escorpiones en el mundo y a pesar de que muy pocas de ellas son consideradas peligrosas para el ser humano se presentan muchos casos de escorpionismo alrededor del mundo. La elaboración de suero antiescorpiónico requiere en primera instancia del establecimiento de una colección en cautiverio para la extracción del veneno, razón por la cual el Instituto Clodomiro Picado (ICP), con una amplia trayectoria en la elaboración de suero antiofídico, inicia en el 2005 una colección para dicho fin. En total 2043 escorpiones clasificados en 11 especies fueron recolectados en un periodo de siete años mediante búsqueda intensiva con luz ultravioleta en varias localidades de la vertiente Pacífica, así como la vertiente Atlántica de Costa Rica. Las extracciones de veneno se realizaron con electro-estimulación, y el veneno recolectado fue caracterizado por el contenido total de proteínas, además se realizaron pruebas de letalidad, siendo Centruroides bicolor el más letal y el que presento los valores más altos en cantidad de veneno y proteínas totales lo cual es consecuente con su masa corporal. Las técnicas empleadas en el mantenimiento en cautiverio de los escorpiones permitieron que los escorpiones vivieran varios años, en un análisis de la longevidad se obtuvieron diferencias significativas entre los géneros $(\mathrm{H}=353.80$; g.1 $=3 ; \mathrm{P}<0.0001)$, siendo el género Didymocentrus el más longevo con un promedio de 4.46 años, un factor importante de su longevidad es el hecho de no haber formado parte del proceso de extracción. También se pudo evidenciar una alta supervivencia de crías nacidas en cautiverio de la especie Tityus pachyurus con respecto a las otras especies del mismo género $(\mathrm{H}=94.32$; g.l $=3$; $\mathrm{P}<0.0001)$, resultado que puede ser tomado en cuenta para reproducir esta especie en cautiverio. El mantenimiento de la colección de escorpiones fue eficiente para el proceso de extracción de veneno y para una supervivencia prolongada de los animales. Existen muy pocas publicaciones en lo que se refiere al mantenimiento de escorpiones en cautiverio para la extracción de veneno por lo que se requiere de una investigación más profunda en aspectos como la reproducción, las causas de muerte y la alimentación.

Palabras clave: escorpiones de Costa Rica, mantenimiento de escorpiones, cautiverio de escorpiones; veneno de escorpiones, extracción de veneno.

\section{REFERENCES}

Batista, C., Román-González, S., Salas-Castillo, S., Zamudio, F., Gómez-Lagunas, F., \& Possani, L. (2007). Proteomic analysis of the venom from the scorpion Tityus stigmurus: Biochemical and physiological comparison with other Tityus species. Comparative Biochemistry and Physiology Part C: Toxicology \& Pharmacology, 146(1-2), 147-157.

Borges, A., Miranda, R., \& Pascale, J. (2012). Scorpionism in Central America, with special reference to the case of Panama. Journal of Venomous Animals and Toxins including Tropical Diseases, 18(2), 130-143.

Candido, D., \& Lucas, S. (2004). Maintenance of scorpions of the genus Tityus Koch (Scorpiones, Buthidae) for venom obtention at Instituto Butantan, Sao Paulo, Brazil. Journal of Venomous Animals and Toxins including Tropical Diseases, 10, 86-97.

Chippaux, J., \& Goyffon, M. (2008). Epidemiology of scorpionism: A global appraisal. Acta Tropica, 107(2), 71-79.

Poggioli De Scannone, J. (1996). Suero antiescorpiónico. Desarrollo y producción. En Instituto Venezolano de Investigaciones Científicas (Ed.), Resúmenes del I Taller los Escorpiones y sus Toxinas. Biología, Clínica y Toxicología (p. 11). Caracas, Venezuela.

Dehghani, R., Vazirianzadeh, B., Nasrabadi, M., \& Moravvej, S. (2010). Study of scorpionism in Kashan in 
central Iran. Pakistan Journal of Medical Sciences, 26(4), 955-958.

Fet, V., \& Soleglad, M. (2005). Contributions to scorpion systematics: On recent changes in high-level taxonomy. Euscorpius, 31, 1-12. Retrieved from http:// mds.marshall.edu/cgi/viewcontent.cgi? article $=1025$ \&context=euscorpius

Francke, O. F., \& Stockwell, S. A. (1987). Scorpions (Arachnida) from Costa Rica. Special Publications the Museum Texas Tech University, 25, 1-64.

Francke, O. F. (1978). Systematic revision of diplocentrid scorpions (Diplocentridae) from Circum-Caribbean lands. USA: Texas Tech Press.14.

Gervais, P. (1843). Les principaux résultats d'un travail sur la famille des Scorpions. Comptes rendus hebdomadaires des séances de l'académie des sciences, 5(7), 129-131.

Gopalakrishnakone, P., Cheah, J., \& Gwee, M. (1995). "Black scorpion (Heterometrus longimanus) as a laboratory animal: maintenance of a colony of scorpion for milking of venom for research, using a restraining device. Laboratory Animals, 29(4), 456-4588.

Isbister, G., Volschenk, E., \& Seymour, J. (2004). Scorpion stings in Australia: five definite stings and a review. Internal Medicine Journal, 34(7), 427-430.

Kraepelin, K. (1911). Neue Beitrage zur systematik der gliederspinnen. Mitteilungen aus dem Naturhistorischen Museum in Hamburg, 28, 59-107.

Laïd, Y., Boutekdjiret, L., Oudjehane, R., Laraba-Djebari, F., Hellal, H., Guerinik, M., ... Chippaux, J. (2012). Incidence and severity of scorpion stings in Algeria. Journal of Venomous Animals and Toxins including Tropical Diseases, 18(4), 399-410.

Leveridge, Y. (2000). Accidente y cuadro clínico por la picadura de alacranes en Costa Rica. Revista Costarricense de Ciencias Médicas, 21, 3-4.

Lourenço, R. W. (1982). Revision du genre Ananteris Thorell, 1891 (Scorpiones: Buthidae) et description de six especes nouvelles. Bulletin de Muséum National d'Histoire Naturelle, 4(1-2), 119-151.

Lourenço, R. W., Cloudsley-Thompson, J., Cuellar, O., Eickstedt, V., Barraviera, B., \& Knox, M. (1996). The evolution of scorpionism in Brazil in recent years. Journal of Venomous Animals and Toxins including Tropical Diseases, 2(2), 121-134.

Lourenço, W. R. 1986. Tityus cerroazul, nouvelle espèce de Scorpion de Panama (Scorpiones, Buthidae). Bulletin de Muséum National d'Histoire Naturelle, 8(3), 637-641.

Oukkache, N., Chgoury, F., Lalaoui, M., Cano, A., \& Ghalim, N. (2013). Comparison between two methods of scorpion venom milking in Morocco. Journal of Venomous Animals and Toxins including Tropical Diseases, 19(1), 1-5.

Pocock, R. (1898). Descriptions of some new scorpions from Central and South America. The Annals and magazine of natural history, 7(1), 384-394.

Polis, G. (1990). The Biology of Scorpions. California: Stanford University Press.

Rein, J. (2013). The Scorpion Files. Trondheim, Norwegian: University of Science and Technology. Retrieved from http://www.ntnu.no/ub/scorpion-files/

Rojas, G., Jiménez, J. M., \& Gutiérrez, J. M. (1993). Caprylic acid fractionation of hyperimmune horse plasma: Description of a simple procedure for antivenom production. Toxicon, 32(3), 351-363.

Solano, G., Segura, A., Herrera, M., Gómez, A., Villalta, M., Gutiérrez, J. M., \& León, G. (2010). Study of the design and analytical properties of the lethality neutralization assay used to estimate antivenom potency against Bothrops asper venom. Biologicals, $38,577-585$.

Víquez, C. (1999). Escorpiones de Costa Rica. Heredia, Costa Rica: INBIO.

Whittemore, F., Keegan, H., Fitzgerald, C., Bryant, H., \& Flanigan, J. (1963). Studies of Scorpion Antivenins. Bulletin World Health Organization, 28, 505-511. 
